\title{
Magnetic Nanoparticles Immobilization and Functionalization for Biosensor Applications
}

\author{
M. B. Mejri, ${ }^{1,2}$ A. Tlili, ${ }^{1}$ and A. Abdelghani ${ }^{1}$ \\ ${ }^{1}$ Nanotechnology Laboratory, Centre Urbain Nord, University of Carthage, INSAT, BP 676, Charguia Cedex 1080, Tunisia \\ ${ }^{2}$ Laboratoire des Maladies Transmissibles et Substances Biologiquement Actives, Université de Monastir, Monastir 5000, Tunisia
}

Correspondence should be addressed to A. Abdelghani, aabdelghan@yahoo.fr

Received 10 April 2011; Revised 5 May 2011; Accepted 5 May 2011

Academic Editor: Vinod Kumar Gupta

Copyright ( $) 2011$ M. B. Mejri et al. This is an open access article distributed under the Creative Commons Attribution License, which permits unrestricted use, distribution, and reproduction in any medium, provided the original work is properly cited.

\begin{abstract}
We describe an approach for E. coli bacteria detection using an electrochemical immunosensor. The immunosensor was based on functionalized magnetic nanoparticles immobilized onto bare gold electrode. Cyclic voltammetry and impedance spectroscopy was performed before and after magnetic nanoparticles deposition. The magnetic nanoparticles functionalized with anti-E. coli polyclonal antibody were used for bacteria detection. Lytic T4-phage was used to confirm the success recognition of bacteria with the developed immunosensor. The specificity of the immunosensor was tested against Enterococcus faecium bacteria. A limit detection of $10^{3} \mathrm{CFU} / \mathrm{mL}$ E. coli bacteria was obtained with a good reproducibility.
\end{abstract}

\section{Introduction}

One of the principal characteristics of E. coli bacteria was their genotypes diversity responsible for diseases. These $E$. coli genotypes called pathotypes lead too much dangerous pathology which affects human and animal species. Currently, we can identify six intestinal pathotypes and two extraintestinal pathotypes agreed by the scientific community [1-3]. Among them, we can cite enterotoxigenic $E$. coli (ETEc) which is frequently an agent of human and animal diarrhea; 600 million cases of human diarrhea and 800.000 worldwide deaths principally in children under the age of five years [4] were attributed to (ETEC) infections. The EPEC infection leads to aqueous diarrhea with some associated pathologic manifestation as vomiting, fever, and dehydration [5-7]. The enteroaggregative E. coli (EAEc) pathology was described as watery diarrhea with the presence of abdominal spasms but no fever. It shows no invasion of blood vessels, but it is marked by persistent rashes and chronic watery diarrhea. Small outbreaks have been recorded both in industrialized countries than in developing countries [8-12].

Toward these inflectional menaces, food contamination is controlled by rigorous legislations [13], and foodborne safety was presented as preventive solution allowing avoiding E. coli diseases. This is why bacterial detection and recognition are principal aims of the health strategies. Conventional methods for E. coli detection were based on bacterial culture and colony counting [14], this way requires $24 \mathrm{~h}$ to yield results and can require up to 7 days for other bacterial strains $[15,16]$. However, biosensors are currently imposed as powerful analytical tools which yield together sensitivity, specificity, and real-time detection. Several successful biosensors for microbial agent were developed [1722], among them are impedimetric biosensors [23, 24]. Magnetic nanoparticles were widely used in the biosensors conceptions [25]. They carry the advantage of increasing the ratio surface/volume, and also it is easy to immobilize to any electrode surface by applying a magnetic field. In previous works, authors were interested in exploiting the high specific interaction between bacteriophages and their target bacteria using various transducers [26]. Lytic phage can be used as a specific bioreceptor allowing bacterial recognition, where the phage-bacteria detection generates dual impedimetric behavior. The first one is corresponding to bacteria immobilization and shows impedance increase, and the second behavior is awarded to bacterial lysis which shows impedance decrease [27]. In this work, we used 
T4 phages as free bioreceptor allowing E. coli bacteria detection as a second tool for our biosensing strategy. Functionalized magnetic nanoparticles immobilized onto a bare gold electrode were used as an immunosensor. Cyclic voltammetry and impedance spectroscopy was performed before and after magnetic nanoparticles deposition. T4phage was used to confirm the success recognition of bacteria with the developed immunosensor. The specificity of the immunosensor was tested against nonspecific Enterococcus faecium bacteria.

\section{Experimental Setup}

2.1. Reagents and Apparatus. The used antibody is goat polyclonal IgG anti-E. coli (ab13627) purchased from Abcam (UK). A phosphate buffer solution (PBS) of $5 \mu \mathrm{g} \mathrm{mL}^{-1}$ of antibody with $\mathrm{pH}=7.2$ was prepared. The magnetic beads used are supplied by Sigma Aldrich (France). They are composed of iron oxide particles coated with a polymer and grafted by $\mathrm{COOH}$ groups, and their diameter is about $200 \mathrm{~nm}$. All other materials, including 1-ethyl-3(3-(dimethylamino)-propyl) carbodiimide (EDC) (Aldrich) and N-hydroxy succinimide (NHS) (Aldrich), were used as supplied.

The buffer solution used was phosphate-buffered saline (PBS) containing $140 \mathrm{mM} \mathrm{NaCl}, 2.7 \mathrm{mM} \mathrm{KCl}, 0.1 \mathrm{Mm}$ $\mathrm{Na}_{2} \mathrm{HPO}_{4}$, and $1.8 \mathrm{mM} \mathrm{KH} \mathrm{PO}_{4}$, at $\mathrm{pH}$ 7.2. This solution was added by a redox couple $\left[\mathrm{Fe}(\mathrm{CN})_{6}\right]^{-4 /-3}(5 \mathrm{mM})$ (ox/red) and used for cyclic voltammetry and impedance spectroscopy. All reagents were of analytical grade, and ultrapure water (resistance $\geq 18.2 \mathrm{M} \Omega \cdot \mathrm{cm}^{-1}$ ) produced by a Millipore Milli-Q system was used.

2.2. Bacterial Culture. E. coli cells were grown in LB broth or on LB agar plates, and Enterococcus faecium cells were grown in BHI broth or on BHI agar plates. High titer of bacteria suspension was prepared as follows: liquid culture mediums were inoculated by $100 \mu \mathrm{L}$ of preculture solution and cultivated at $37^{\circ} \mathrm{C}$ for $8-10 \mathrm{~h}$. Centrifuge the cells at $6200 \mathrm{rpm}$ for $5 \mathrm{~min}$, wash the cells twice, and resuspend the cells in sterile PBS. Determine the viable cells and bacterial concentration with spread-plate technique. The optical density OD of the bacterial culture has been measured for the determination of bacterial growth stationary phase.

2.3. Phage Culture. The E. coli K12 liquid culture mediums were inoculated at exponential phase with $500 \mu \mathrm{L}$ of phage$\mathrm{T} 4$ solution and were incubated at $37^{\circ} \mathrm{C}$ in a rotary shaker (200 rpm) for three hours. Chloroform was added to final concentration of $10 \%$ and kept at $4^{\circ} \mathrm{C}$ for $20 \mathrm{~min}$ before centrifugation at $4^{\circ} \mathrm{C}(19000 \mathrm{~g})$. Double-layer plates of each phage dilutions were prepared to give confluent lysis of the indicator strain E. coli K12. This allows us to determine the phage concentration in PFU.

2.4. Gold Cleaning. Gold substrates were provided by the Neuchatel Institute (Switzerland). They were fabricated using standard silicon technologies. (100)-oriented, P-type

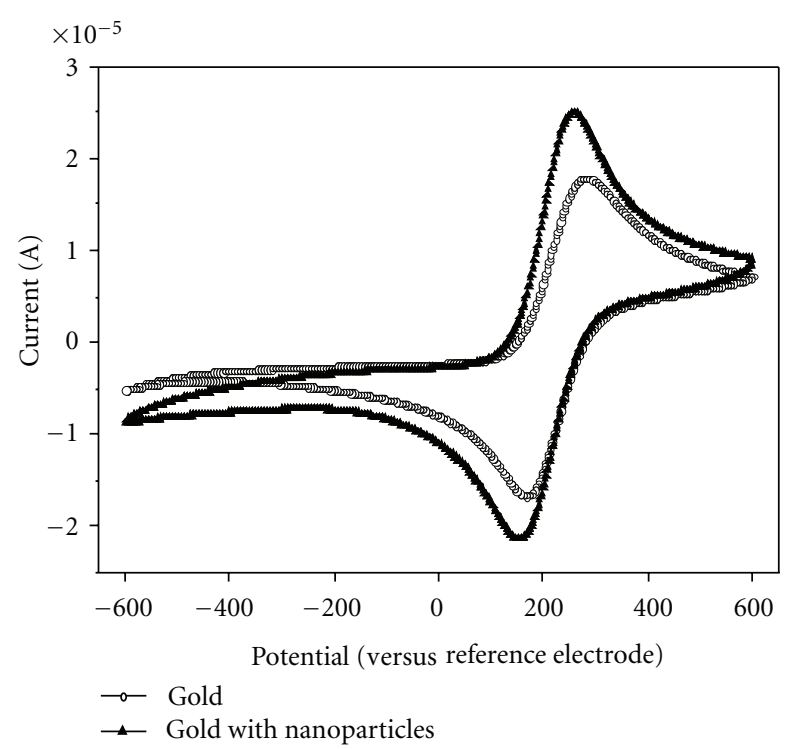

Figure 1: Cyclic voltammograms of (a) bare gold electrode; (b) bare gold electrode/magnetic beads. In presence of a $5 \mathrm{mM}$ redox, probe $\mathrm{K}_{3}\left[\mathrm{Fe}(\mathrm{CN})_{6}\right] / \mathrm{K}_{4}\left[\mathrm{Fe}(\mathrm{CN})_{6}\right]$ versus SCE.

$(3-5 \Omega \cdot \mathrm{cm})$ silicon wafers were thermally oxidized to grow an $800 \mathrm{~nm}$-thick field oxide. Then, a $30 \mathrm{~nm}$ thick titanium layer and a $300 \mathrm{~nm}$-thick gold top layer were deposited by evaporation under vacuum. Before modification, the gold electrodes were cleaned in acetone solution for $20 \mathrm{~min}$ with ultrasonic bath. After that, they were dried under a nitrogen flow and then dipped for $10 \mathrm{~min}$ into "piranha solution" $7: 3(\mathrm{v} / \mathrm{v}) 96 \% \mathrm{H}_{2} \mathrm{SO}_{4} / 30 \% \mathrm{H}_{2} \mathrm{O}_{2}$. Finally, the gold substrates were rinsed 2 to 3 times with ultrapure water and immediately immersed in an ethanol solution and finally dried under nitrogen flow.

2.5. Magnetic Nanoparticles Functionalization. The stock solution of carboxylic magnetic nanoparticles was diluted in ultrapure water. A volume of $40 \mu \mathrm{L}$ of the diluted solution of nanoparticles was injected onto a cleaned gold electrode already positioned in an electrochemical cell. A magnetic field of $300 \mathrm{mT}$ was applied during all the measurements using a cylindrical magnet. The magnetic nanoparticles layer was formed on the gold surface. The immobilized nanoparticles were treated with $0.4 \mathrm{Mm}$ EDC-0.1 mM NHS for $1 \mathrm{~h}$ to convert the terminal carboxylic groups to an active NHS ester. The polyclonal antibodies solution $\left(5 \mu \mathrm{g} \mathrm{mL}^{-1}\right)$ was dropped on the gold surface for $1 \mathrm{~h}$ at room temperature. Modified electrode was finally treated by BSA solution (1\%) to block the nonspecific sites.

2.6. Cyclic Voltammetry. The deposition of magnetic nanoparticles onto gold electrode was checked with cyclic voltammetry. Measurements were recorded in PBS solution with redox couple $\left(\left[\mathrm{Fe}(\mathrm{CN})_{6}\right]^{-4 /-3}\right)$, using a scanning potential sweep from $-700 \mathrm{mV}$ to $700 \mathrm{mV}$ with a scan rate of $100 \mathrm{mV} / \mathrm{s}$. 


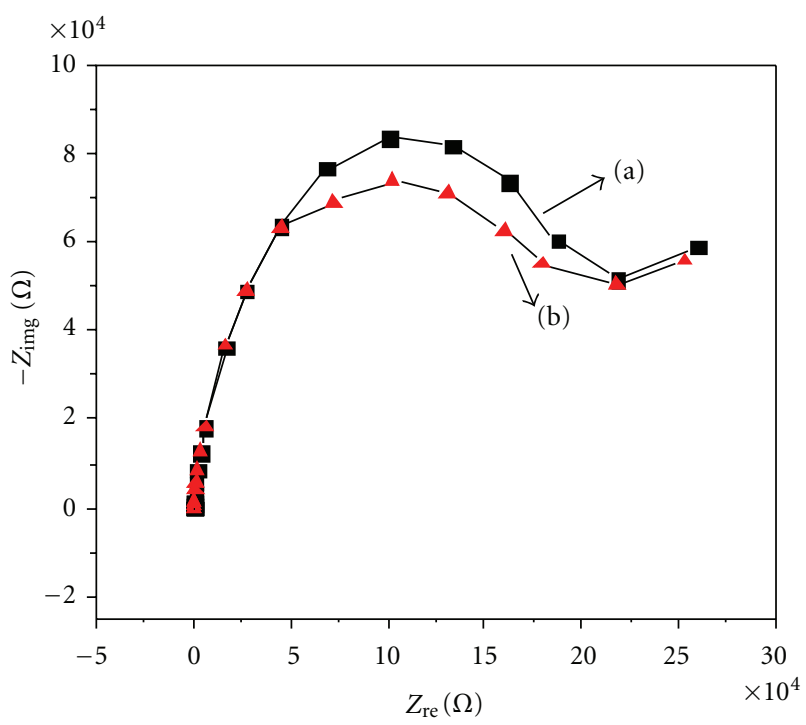

FIGURE 2: Impedance spectra of (a) bare gold electrode; (b) bare gold electrode functionalized with magnetic nanoparticles.

2.7. Electrochemical Impedance Spectroscopy. Conventional electrochemical cell with a three-electrode configuration was used to measure impedance spectroscopy. Modified gold electrode was considered as working electrode $\left(0.11 \mathrm{~cm}^{2}\right)$, a platinum electrode $\left(0.54 \mathrm{~cm}^{2}\right)$ as the counterelectrode, and a saturated calomel electrode (SCE) as the reference electrode. The impedance spectra were recorded in a frequency range from $50 \mathrm{mHz}$ to $100 \mathrm{kHz}$, and apparatus used in all electrochemical measurements is an Autolab $302 \mathrm{~N}$ impedance analyser (Ecochemie, The Netherlands) equipped with the NOVA1.4 acquisition software.

\section{Results and Discussions}

\subsection{Characterization of Magnetic Nanoparticles Layer}

3.1.1. Cyclic Voltammetry. Figure 1 shows the cyclic voltammetry measurement of bare gold surface before and after magnetic nanoparticles immobilization. A reversible voltammogram corresponding to a bare cleaned gold electrode can be observed. The two observed peaks correspond to the oxydoreduction potential of the used redox couple $\left[\mathrm{Fe}(\mathrm{CN})_{6}\right]^{-4 /-3}$. The success immobilization of magnetic nanoparticles was confirmed with the increase of the current. This indicates that the resistance decreases due to the presence of the magnetic beads covering the electrode.

3.1.2. Electrochemical Impedance Spectroscopy. Figure 2 shows the electrochemical impedance spectra of gold bare electrode before and after the deposition of magnetic nanoparticles layer at $0 \mathrm{~V}$. The obtained spectra can be modelized with an electric model shown in a previous work [19]. The diameter of semicircle corresponds to the charge transfer resistance of the electrode/electrolyte interface. The decrease of the charge transfer resistance is due to the conductivity

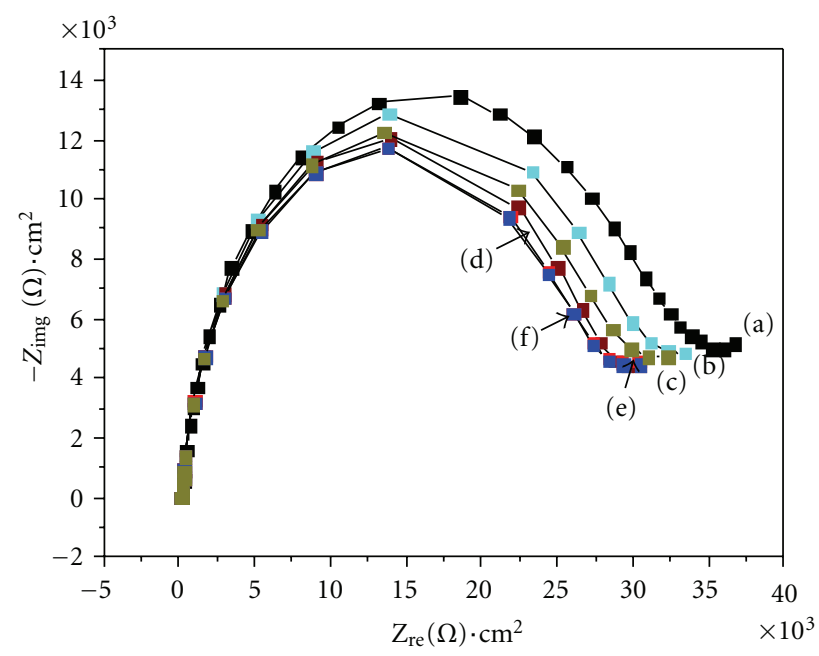

FIGURE 3: Impedance spectra of (a) bare gold electrode/magnetic beads/polyclonal Ab anti-E. coli; (b) $10^{3} \mathrm{CFU} / \mathrm{mL}$; (c) $10^{4} \mathrm{CFU} / \mathrm{mL}$; (d) $10^{5} \mathrm{CFU} / \mathrm{mL}$; (e) $10^{6} \mathrm{CFU} / \mathrm{mL}$; (f) $10^{7} \mathrm{CFU} / \mathrm{mL}$; (f=g) $10^{8} \mathrm{CFU} /$ $\mathrm{mL}$.

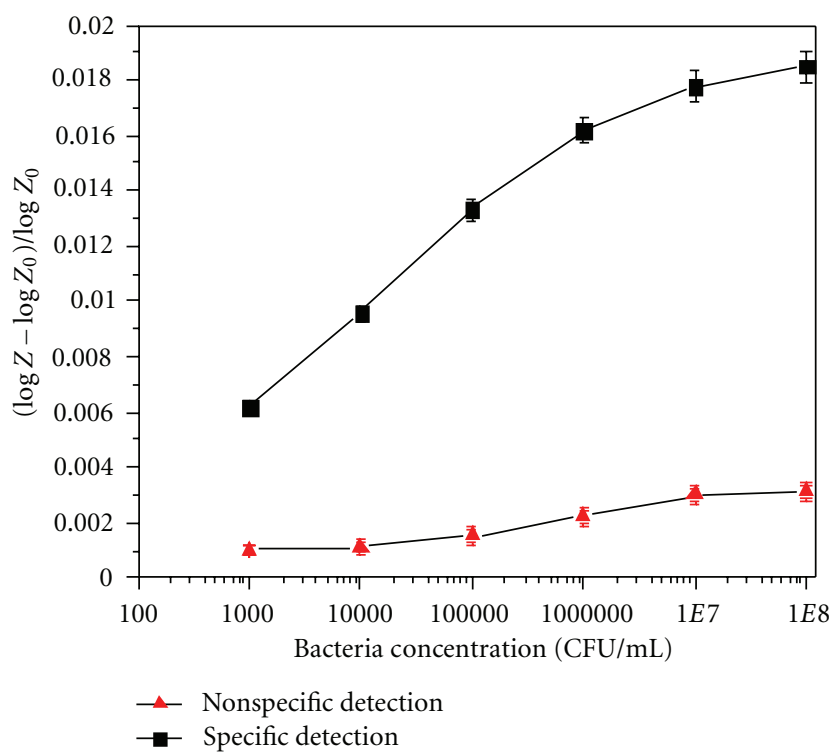

FIGURE 4: Calibration curve: the variation of the absolute value of $\left|\left(\log Z-\log Z_{0}\right) / \log Z_{0}\right|$ versus bacteria concentration $(\mathrm{CFU} / \mathrm{mL})$ at $233 \mathrm{mHz}$. The specific detection was with E. coli and nonspecific detection with Enterococcus faecium bacteria.

increase at the gold-electrolyte interface after magnetic nano-particles immobilization.

3.2. Bacteria Immunodetection. The immunodetection of E. coli bacteria was performed in an electrochemical cell containing sterile PBS. Different volumes corresponding to different bacterial concentrations in $\mathrm{CFU} / \mathrm{mL}$ were injected. Figure 3 shows the impedance spectra obtained after different bacteria concentrations injection (between $10^{3}$ and $10^{8} \mathrm{CFU} / \mathrm{mL}$ ). The decrease of the charge transfer resistance 


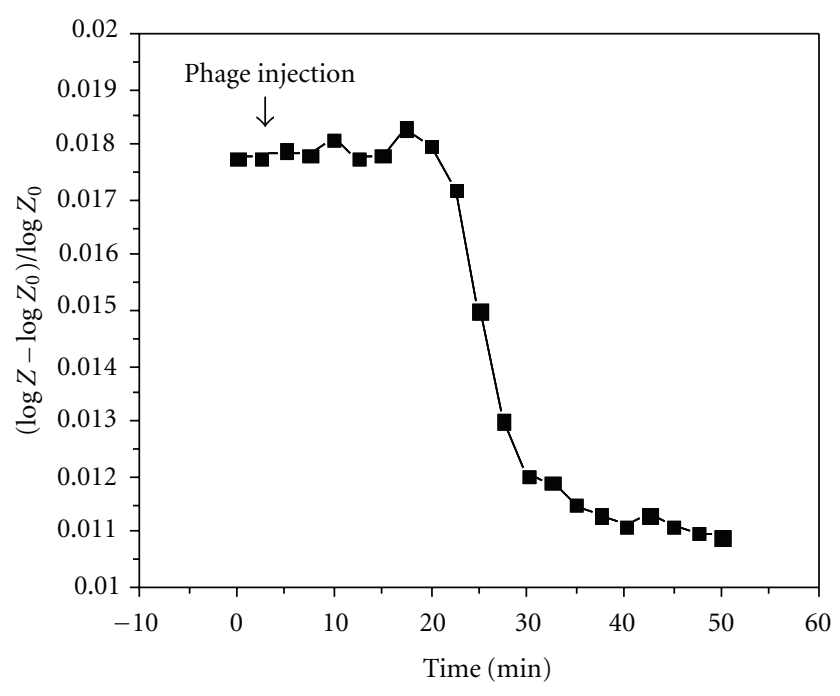

Figure 5: Variation of the absolute value of $\mid(\log Z-$ $\left.\log Z_{0}\right) / \log Z_{0} \mid$ after phage injection versus time at a fixed frequency of $233 \mathrm{mHz}$. E. coli bacteria concentration is $10^{7} \mathrm{CFU} /$ $\mathrm{mL}$.

is due to the specific bacteria recognition. The resistance decreases gradually as the bacteria concentration increases. This decrease is different from the previous results obtained without magnetic nanoparticles [27] where we have an impedance increase. A saturation behavior was reached at a concentration of $10^{7} \mathrm{CFU} / \mathrm{mL}$.

A calibration curve was obtained by calculating the absolute value of $\left(\log Z-\log Z_{0}\right) / \log Z_{0}$ at a fixed frequency $(233 \mathrm{mHz})$, where $Z$ is the value of the impedance after bacteria binding to antibody, $Z_{0}$ is the value of impedance only with the antibody. Figure 4 shows a linear increase of the absolute value of the impedance and a beginning of saturation for higher bacteria concentrations. The detection limit of $10^{3} \mathrm{CFU} / \mathrm{mL}$ was obtained with a good reproducibility. The negative test was performed by injecting several concentrations of Enterococcus faecium bacteria. The absence of any significant change confirms the specificity of the developed immunosensor.

3.3. T4-Phage Injection. We used lytic phage (T4-phage) as second recognition to confirm the previous signal generated by the immunosensor. For this purpose, we inject a concentration $\left(10^{7} \mathrm{CFU} / \mathrm{mL}\right)$ of $\mathrm{T} 4$ phage onto the functionalized gold electrode after E. coli recognition. A $50 \mu \mathrm{L}$ of T4 phage solution was introduced into electrochemical cell where immunosensor was already saturated with the bacteria $\left(10^{7} \mathrm{CFU} / \mathrm{mL}\right)$. As it is shown in Figure 5, a stable impedimetric behavior was recorded, while after $15 \mathrm{~min}$, a strong decrease of the absolute value of the impedance was observed. This kinetic behavior is typical for phage-bacteria interaction [27] and confirms the immunosensing results.

\section{Conclusion}

In this work, we describe an approach for E. coli bacteria detection using immunosensor based on functionalized magnetic nanoparticles immobilized onto a bare gold electrode. Cyclic voltammetry and impedance spectroscopy was performed before and after magnetic nanoparticles deposition. The magnetic nanoparticles functionalized with polyclonal antibody were used for E. coli detection. T4phage was used to confirm the success recognition of bacteria by the developed immunosensor. The specificity of the immunosensor was tested against Enterococcus faecium bacteria. A limit detection of $10^{+03} \mathrm{CFU} / \mathrm{mL}$ was obtained with a good reproducibility. For future work, interdigitated microelectrodes arrays integrated in microfluidic cell will be used to perform limit detection and sensitivity.

\section{Acknowledgments}

Dr. A. Abdelghani thanks the Alexander Von Humboldt Stiftung (Germany) for the material donation. The authors thank Biophage Pharma (Canada) for providing them T4phage, Dr. Mohamed Zourob (Canada), Professor A. Simonian (USA), Dr. Eva Baldrich (CNM Barcelona, Spain), F. J. Del Campo (CNM Barcelona, Spain), and Professor N. Jaffrezic-Renault (France) for their collaboration.

\section{References}

[1] J. P. Nataro and J. B. Kaper, "Diarrheagenic Escherichia coli," Clinical Microbiology Reviews, vol. 11, no. 1, pp. 142-201, 1998.

[2] J. P. Nataro, T. Steiner, and R. L. Guerrant, "Enteroaggregative Escherichia coli," Emerging Infectious Diseases, vol. 4, no. 2, pp. 251-261, 1998.

[3] J. B. Kaper, J. P. Nataro, and H. L. T. Mobley, "Pathogenic Escherichia coli," Nature Reviews Microbiology, vol. 2, no. 2, pp. 123-140, 2004.

[4] World Health Organization, The World Health Report 1999: Making a Difference, World Health Organization, Geneva, Switzerland, 1999.

[5] A. E. Jerse, J. Yu, B. D. Tall, and J. B. Kaper, "A genetic locus of enteropathogenic Escherichia coli necessary for the production of attaching and effacing lesions on tissue culture cells," Proceedings of the National Academy of Sciences of the United States, vol. 87, no. 20, pp. 7839-7843, 1990.

[6] B. Kenny, R. DeVinney, M. Stein, D. J. Reinscheid, E. A. Frey, and B. B. Finlay, "Enteropathogenic E. coli (EPEC) transfers its receptor for intimate adherence into mammalian cells," Cell, vol. 91, no. 4, pp. 511-520, 1997.

[7] C. S. Tailor, A. Nour, C. G. Lee, C. Kozak, and D. Kabat, "Cloning and characterization of a cell surface receptor for xenotropic and polytropic murine leukemia viruses," Proceedings of the National Academy of Sciences of the United States, vol. 96, no. 3, pp. 927-932, 1999.

[8] J. P. Nataro, J. B. Kaper, R. Robins-Browne, V. Prado, P. Vial, and M. M. Levine, "Patterns of adherence of diarrheagenic Escherichia coli to HEp-2 cells," Pediatric Infectious Disease Journal, vol. 6, no. 9, pp. 829-831, 1987.

[9] J. P. Nataro, Y. Deng, S. Cookson et al., "Heterogeneity of enteroaggregative Escherichia coil virulence demonstrated in volunteers," Journal of Infectious Diseases, vol. 171, no. 2, pp. 465-468, 1995.

[10] I. C. A. Scaletsky, S. H. Fabbricotti, R. L. B. Carvalho et al., "Diffusely adherent Escherichia coli as a cause of acute diarrhea 
in young children in northeast Brazil: a case-control study," Journal of Clinical Microbiology, vol. 40, no. 2, pp. 645-648, 2002.

[11] J. R. Johnson, T. T. O’Bryan, P. Delavari et al., "Clonal relationships and extended virulence genotypes among Escherichia coli isolates from women with a first or recurrent episode of cystitis," Journal of Infectious Diseases, vol. 183, no. 10, pp. 1508-1517, 2001.

[12] J. R. Johnson, S. J. Weissman, A. L. Stell, E. Trintchina, D. E. Dykhuizen, and E. V. Sokurenko, "Clonal and pathotypic analysis of archetypal Escherichia coli cystitis isolate NU14," Journal of Infectious Diseases, vol. 184, no. 12, pp. 1556-1565, 2001.

[13] WHO, International Health Regulations. The Fifty-Eighth World Health Assembly, World Health Organization, Geneva, Switzerland, 2005.

[14] H. Ayçiçek, H. Aydogan, A. Küçükkaraaslan, M. Baysallar, and A. C. Basustaoglu, "Assessment of the bacterial contamination on hands of hospital food handlers," Food Control, vol. 15, pp. 253-254, 2004.

[15] S. Artault, J. L. Blind, J. Delaval, Y. Dureuil, and N. Gaillard, "Detecting Listeria monocytogenes in food," International Food Hygiene, vol. 12, p. 23, 2001.

[16] E. Deboer and R. R. Beumer, "Methodology for detection and typing of foodborne micro-organisms," The International Journal of Food Microbiology, vol. 50, pp. 119-130, 1999.

[17] W.M. Hassen, C. Chaix, A. Abdelghani, F. Bessueille, D. Leonard, and N. Jaffrezic, "An impedimetric DNA sensor based on functionalized magnetic nanoparticles for HIV and HBV detection," Sensors \&Actuators B, vol. 134, no. 2, pp. 755760, 2008.

[18] M. Hnaien, M. F. Diouani, S. Helali et al., "Immobilization of specific antibody on SAM functionalized gold electrode for rabies virus detection by electrochemical impedance spectroscopy," Biochemical Engineering Journal, vol. 39, no. 3, pp. 443-449, 2008.

[19] M. F. Diouani, S. Helali, I. Hafaid et al., "Miniaturized biosensor for avian influenza virus detection," Materials Science and Engineering C, vol. 28, no. 5-6, pp. 580-583, 2008.

[20] M. G. Silva, S. Helali, C. Esseghaier, C. E. Suarez, A. Oliva, and A. Abdelghani, "An impedance spectroscopy method for the detection and evaluation of Babesia bovis antibodies in cattle," Sensors \& Actuators B, vol. 135, no. 1, pp. 206-213, 2008.

[21] M. B. Mejri, M. Marrakchi, H. Baccar et al., "Electrochemical impedance spectroscopy for specific detection of enterovirus," Sensor Letters, vol. 7, no. 5, pp. 896-899, 2009.

[22] H. Baccar, M. B. Mejri, I. Hafaiedh, T. Ktari, M. Aouni, and A. Abdelghani, "Surface plasmon resonance immunosensor for bacteria detection," Talanta, vol. 82, pp. 810-814, 2010.

[23] L. I. Yang, Y. B. Li, C. L. Griffis, and M. G. Johnson, "Interdigitated microelectrode (IME) impedance sensor for the detection of viable Salmonella typhimurium," Biosensors \& Bioelectronics, vol. 19, no. 10, pp. 1139-1147, 2004.

[24] L. Yang and R. Bashir, "Electrical/electrochemical impedance for rapid detection of foodborne pathogenic bacteria," Biotechnology Advances, vol. 26, no. 2, pp. 135-150, 2008.

[25] M. Varshney and Y. Li, "Interdigitated array microelectrode based impedance biosensor coupled with magnetic nanoparticle-antibody conjugates for detection of Escherichia coli O157:H7 in food samples," Biosensors \& Bioelectronics, vol. 22, no. 11, pp. 2408-2414, 2007.

[26] S. Balasubramanian, I. B. Sorokulova, V. J. Vodyanoy, and A. L. Simonian, "Lytic phage as a specific and selective probe for detection of Staphylococcus aureus-a surface plasmon resonance spectroscopic study," Biosensors \& Bioelectronics, vol. 22, no. 6, pp. 948-955, 2006.

[27] M. B. Mejri, H. Baccar, E. Baldrich et al., "Impedance biosensing using phages for bacteria detection: generation of dual signals as the clue for in-chip assay confirmation," Biosensors \& Bioelectronics, vol. 26, no. 4, pp. 1261-1267, 2010. 


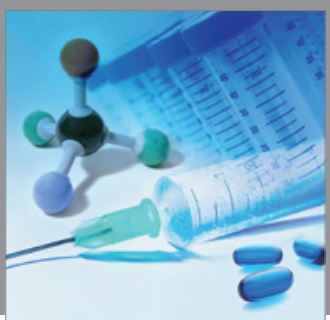

International Journal of

Medicinal Chemistry

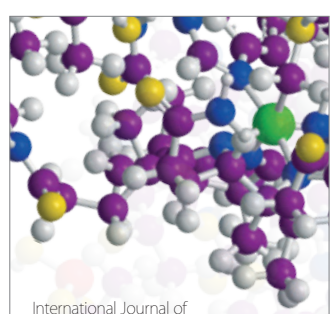

Carbohydrate Chemistry

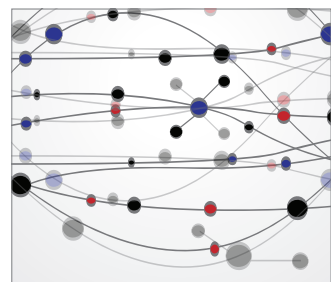

The Scientific World Journal
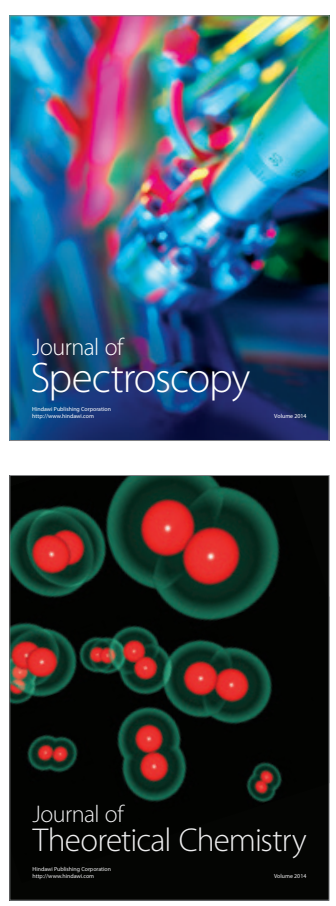
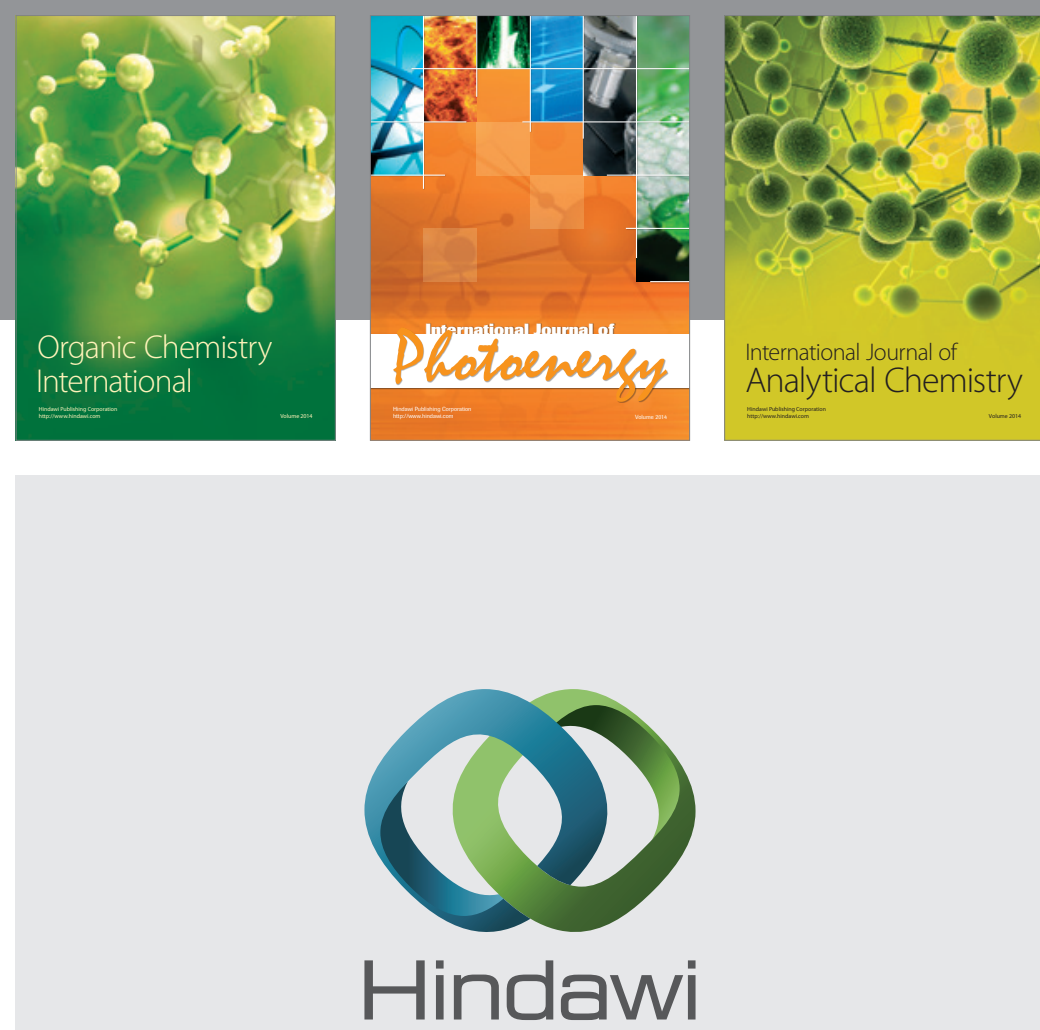

Submit your manuscripts at

http://www.hindawi.com
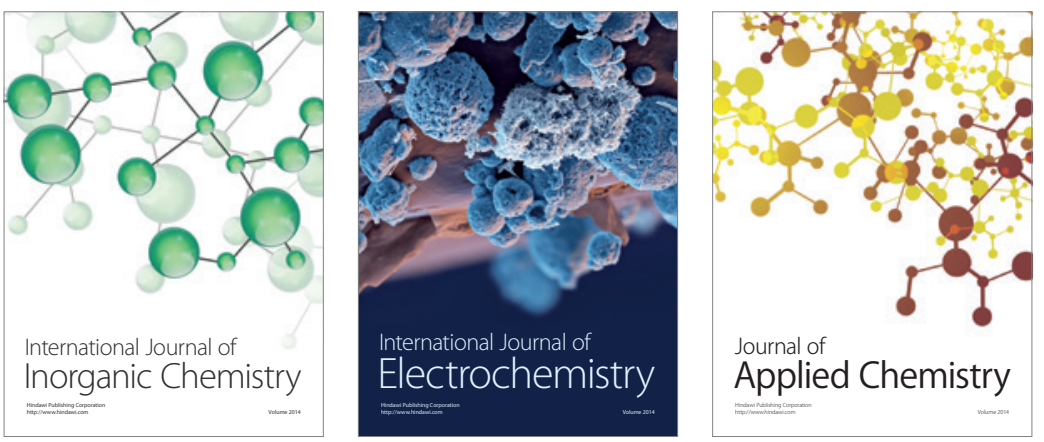

Journal of

Applied Chemistry
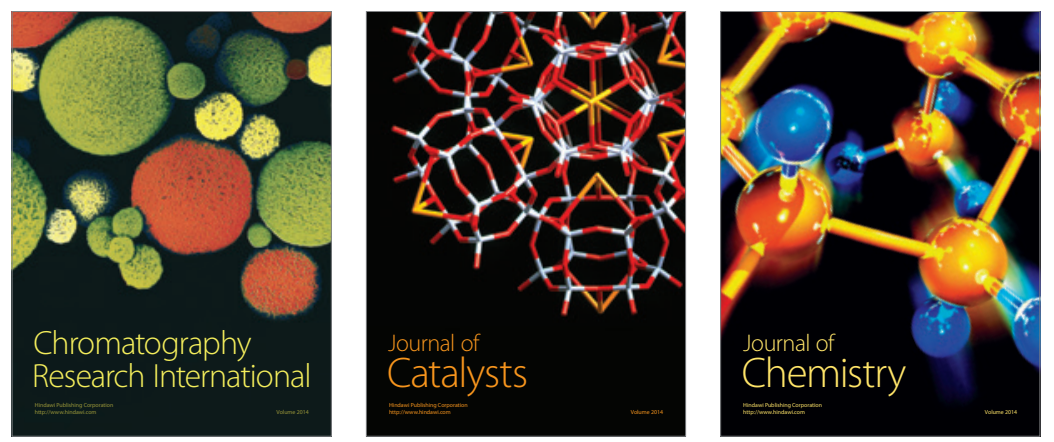
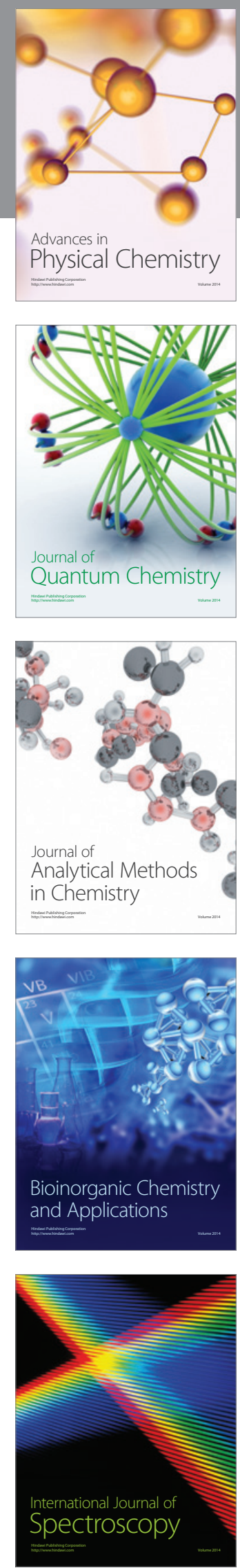